Mount, M.S. and P.M. Berman. 1994. Genetic manipulation of plants to improve postharvest disease resistance. HortScience 29:762-768.

Poovaiah, B.W., G.M. Glenn, and A.S.N. Reddy. 1988. Calcium and fruit softening: Physiology and biochemistry. Hort. Rev. 10:107-151.

Pusey, P.L. 1989. Use of Bacillus subtilis and related organisms as biofungicides. Pesticide Sci. 27:133-140.

Simmonds, J.H. 1963. Studies in the latent phase of Colletrotichum species concerning ripe rots of tropical fruits. Queensland J. Agr. Sci. 20:373-424

Swinburne, T.R. 1983. Quiescent infections in post-harvest diseases, p. 1-21.
In: C. Dennis (ed.). Post-harvest pathology of fruits and vegetables. Academic, New York.

Verhoeff, K. 1974. Latent infections by fungi. Annu. Rev. Phytopathol. 12:99110 .

Wells, J.M. 1971. Postharvest hot-water and fungicide treatments for reduction of decay of California peaches, plums, and nectarines. U.S. Dept. Agr. Market Res. Rpt. 980.

Wood, R.K.S. 1967. Physiological plant pathology. Blackwell Scientific, Oxford, England.

\title{
Latent Infections in the Pre- and Postharvest Environment
}

\author{
William R. Jarvis \\ Agriculture Canada, Research Station, Harrow, Ont. NOR I GO, Canada
}

For the epidemiologist, latency is the period from infection until the infected tissue becomes infectious, "spore-to-spore" (Vanderplank, 1963), but it generally has come to mean a period of pathogen quiescence (Verhoeff, 1974), sometimes even extended to cover the time when microorganisms lie quiescent on the host surface before infection occurs. In managing diseases of horticultural crops, pathogen quiescence has important implications in timing prophylaxis, the reduction of stresses that trigger the transition of quiescence to aggression, and managing the harvested crop to prolong quiescence to the point at which yield is no longer affected.

The inception of pathogen quiescence and its maintenance on or within the host implies a dynamic equilibrium between the host, the pathogen, and their environment. Physiological and physical changes in the host, its environment, or both trigger changes in that equilibrium to permit the pathogen to resume aggression. Microorganisms lying on the host surface constitute a potential latent infection; as can be the case with Botrytis cinerea Pers. :Fr. conidia that are prevented from germinating by antagonistic bacteria on leaf surfaces (Blakeman and Fokkema, 1982; Cline, 1985). Quiescence can run the spectrum from the ungerminated spore; through symptomless, internal infections; to visible but nonexpanding lesions, such as ghost spot of tomato (Lycopersicon esculentum Mill.) (Verhoeff, 1970); to expanding lesions on banana (Musa $\times$ paradisiaca $\mathrm{L}$.), caused by Colletotrichum musae (Berk. \& M.A. Curtis) Arx (Simmonds, 1941), and on avocado (Persea americana Mill.), caused by C. gloeosporioides (Penz.) Penz. $\&$ Sacc. (Binyamini and Schiffmann-Nadel, 1972). With the exception of tomato ghost spot, most quiescent infections eventually become aggressive rots in the field and, if undetected, in stored and marketed produce.

Quiescent infections are common in a wide variety of fruit, vegetable, and floral crops. They are caused by bacteria (Bartz, 1981; Hayward, 1974; Leben, 1981) and fungi (Baker et al., 1940; Jenkins and Reinganum, 1965; Rosenberger, 1983; Swinburne, 1983; Verhoeff, 1974). Soft rot bacteria are common in apparently healthy tomatoes (Bartz, 1981; Samish and Etinger-Tulczynska, 1963), cucumbers (Cucumis sativus L.) (Leben, 1981; Menelly and Stanghellini, 1975; Samish and Dimant, 1959), and potato (Solarium tuberosum L.) tubers (Perombelon and Kelman, 1988). Also in potatoes, quiescent Clavibacter michiganense subsp. sepedonicum (Spieck. \& Koth) Davis et al. is a serious impediment to export trade (de Boer and McNaughton, 1986). The world's three most important small-berry crops, grapes (Vitis vinifera L.) (McClellan and Hewitt, 1973; Pezet and Pent, 1986), strawberries (Fragaria $\times$ ananassa Duch.) (Jarvis, 1962; Powelson, 1960), and raspberries (Rubus idaeus L.) (Bristow et al., 1986; Jarvis, 1962; Powelson, 1960; Williamson et al., 1987), all have quiescent infections of Botrytis cinerea established in their floral parts; these infections usually become aggressive in ripe fruit. However, aggression may be significantly advanced in wet weather, when, for example, normally resistant green strawberries succumb to gray mold. Botrytis cinerea also can establish a quiescent infection in apple (Malus domestics Borkh.) calyx, which becomes eye rot (Tronsmo and Raa, 1977), and in fruit wounds (Lakshiminarayana et al., 1987).
Quiescent petal flecking in many floral crops is also frequently caused by B. cinerea (Cline, 1985) and other host-specific Botrytis spp. in the monocotyledonous Corolliferae and the Ranunculaceae (Jarvis, 1977). In the Sclerotiniaceae, Monilinia fructicola (G. Wint.) Honey is quiescent in stone fruits (Jenkins and Reinganum, 1965), and Sclerotinia sclerotiorum (Lib.) de Bary is quiescent in many vegetables (Smith et al., 1966), including carrots (Daucus carota L.) (Tahvonen, 1985). Botrytis aclada Fresen. is quiescent in onions (Allium cepa L.) (Tichelaar, 1967) and is responsible for neck rot in storage. Outside the Sclerotiniaceae, Colletotrichum spp. are common quiescent pathogens of tropical fruit (Baker et al., 1940; Binyamini and SchiffmannNadel, 1972; Simmonds, 1941).

\section{Mechanisms of quiescence}

In most unripe fruit and stem and root vegetables, the mechanisms limiting pathogen aggression are associated with either preformed antimicrobial substances (phytoncides) or with phytoalexins, enzymes, or physically resistant structures. A wide variety of postulates have been, or can be, advanced to explain quiescence (Dennis, 1983; Hayward, 1974; Verhoeff, 1974). Most of these postulate that aggression begins when certain physiological and physical changes occur, particularly in the host cell wall (Fisher and Bennett, 199 1; Hondelmann and Richter, 1973). The changes in dynamic equilibrium between climacteric metabolism and the strains induced by the stress of infection involve ethylene production (Takeda and Nakamura, 1990). Other stresses are imposed by such factors as wounding (Bruton, 1994), an unduly wet flowering season in strawberries, harvesting in potatoes, and inappropriate storage conditions.

\section{Implications of quiescence in disease control}

Setting aside the epiphytic populations of potential pathogens on plant surfaces, which may be controlled by pesticides (Fokkema and de Nooij, 1981) and biological agents (Blakeman and Fokkema, 1982; Wilson, 1989), the infection process, as defined by breaching the host epidermis, may occur several days or weeks before symptoms appear. This means that it is essential to know what environmental conditions permit infection to occur. In strawberries, white flower buds and fully open flowers are the most susceptible to infection, and the calyx and corolla are more susceptible than the receptacle (Jarvis and Borecka, 1968). Strawberries and raspberries present a difficult problem in timing prophylaxis because of the cymose inflorescences' long development sequence (Jarvis, 1969). This situation is further complicated by the finding that first-formed berries in the strawberry inflorescence are more susceptible to gray mold than successively later berries on the same inflorescence (Grainger, 1956). That microorganisms must be prevented from breaching the host epidermis means that the choice of pesticide is restricted to those that act on contact with the pathogen on the host surface; systemic, eradicant pesticides are less successful since they usually act imperfectly after infection. 
Phonological and epidemiological studies permit formulating forecasting methods. The complex phenology of strawberries and raspberries makes forecasting difficult, but it has been done for grapes, which have a well-defined bloom period (Bourdier, 1986; Egger, 1986), and for which the microclimates conducive to $B$. cinerea infection are known (Jarvis, 1980). Precise control over greenhouse microclimates permits designing effective disease prevention strategies for protected crops (Jarvis, 1992; Marois et al., 1988).

\section{Prophylaxis}

Once the climatic and phonological conditions that permit initial infection to occur (Bulger et al., 1987; Johnson and Powelson, 1983; McNicol et al.. 1990) are established, pesticide application may be timed accurately, usually well in advance of harvesting, so that undue residues are avoided. Several studies have shown that fruit crops are better protected by applying pesticides during bloom rather than later (Kable, 1971; Mason and Dennis, 1978; McClellan et al., 1973), and that vegetable crops store better when infections are controlled in the field (Tahvonen, 1985).

Disease prevention measures can also be devised for crops in the field. Thus, green beans escape gray mold and white mold infection if the plant architecture and row orientation permits floral parts to dry rapidly (Campbell, 1949; Johnson and Powelson, 1983). Tomatoes may escape gray mold if the correct soil N (Verhoeff, 1968) and Ca levels are maintained (Stall et al., 1965).

\section{Prolonging quiescence}

Even if tissues are infected quiescently, it still maybe possible to obtain blemish-free floral crops or rot-free fruit and vegetables by manipulating the crop so that aggression is not triggered. How this may be done, however, is not widely understood. Water content of tissues seems to be important; for example, green strawberries are very susceptible to B. cinerea in wet weather (Jarvis, 1964), an effect simulated by supplying water directly into the fruit pedicel (Jarvis, 1963).

The development of quiescent neck rot infections (Botrytis aclada) in onions depends on adequate moisture in the senescing green leaf tissue (Tichelaar, 1967). If onions are dried adequately in windrows or cured artificially before storage (Harrow and Harris, 1969), neck rot ceases to be a problem. Similarly, root crops with green leaves, like carrots, or senescent outer leaves, like cabbage (Brassica oleracea L. Capitata Group), should be carefully trimmed and dried before storage (Swinburne, 1983; Tahvonen, 1985). Correct mineral nutrition prolongs the quiescent phase (Conway et al., 1994). The effect of soil $\mathrm{N}$ in prolonging the quiescent phase of $B$. cinerea in tomato stem tissue seems to be one of delaying tissue senescence (Verhoeff, 1968). Biological control can be applied rationally to prolong quiescence (Roberts, 1994; Wilson, 1989).

The temperature of insolated fruit is also important; in picked fruit left in the sun, the temperature maybe 8 to $10 \mathrm{C}$ higher than ambient air temperature (Schroeder, 1965). Experience has shown that most fruits are best picked in the early morning; they have a longer shelf life if field heat is removed before shipping.

\section{Conclusion}

Quiescent infections are common in a wide variety of horticultural crops, but while it is well established that bloom period prophylaxis gives protection to ripening fruit crops, the manner in which aggression is triggered is poorly understood. Devising disease prevention measures by delaying the onset of pathogen aggression depends on better knowledge of host-parasite interactions during ripening. In particular, environmental stresses that trigger aggression have to be identified and controlled in the field and in storage.

\section{Literature Cited}

Baker, R.E.D., S.H. Crowdy, and R.K. McKee. 1940. A review of latent infections caused by Colletotrichum gloeosporioides and allied fungi. Trop, Agr. 17:128-132.
Bartz, J.A. 1981. Variation in the latent period of bacterial soft rot in tomato fruit. Phytopathology 71:1057-1062.

Binyamini, N. and M. Schiffmann-Nadel. 1972. Latent infection in avocado fruit due to Colletotrichum gloeosporioides. Phytopathology 62:592-594.

Blakeman, J.P. and N.J. Fokkema. 1982. Potential for biological control of plant diseases in the phyllosphere, Annu. Rev. Phytopathol. 20:167-192.

de Boer, S.H. and M.E. McNaughton. 1986. Evaluation of immunofluorescence with monoclinal antibodies for detecting latent bacterial ring rot infections. Amer. Potato J. 57:457465.

Bourdier, L. 1986. Lamodélisation: Un outil nouveau contre le Botryis cinerea chez la vigne. Comptes Rendus Académie Agr. Francaise 72:763-771,

Bristow, P.R., R.J. McNicol, and B. Williamson. 1986. Infection of strawberry flowers by Botrytis cinerea and its relevance to grey mould development. Ann, Appl. Biol. 109:545-554.

Bruton, B.D. 1994. Mechanical injury and latent infections leading to postharvest decay. HortScience 29:747-749.

Bulger, M. A., M.A. Ellis, and L.V. Madden. 1987. Influence of temperature and wetness duration on infection of strawberry flowers by Botrytis cinerea and disease incidence originating from infected flowers. Phytopathology 77:1225-1230.

Campbell, L. 1949. Gray mold of beans in western Washington. Plant Dis. Rpt. 33:91-93.

Cline, M.N. 1985. Botrytis blight Evidence for latency and/or phylloplane residence during storage and shipment of selected floral crops, Quad. Scuola Spec. Viticult. Enol. 9:253-254. (Abstr.)

Conway, W. S., C.E. Sams, and A. Kelman. 1994. Enhancing the natural resistance of plant tissues to postharvest disease through calcium applications. HortScience 29:751-754.

Dennis, C. (ed.). 1983. Post-harvest pathology of fruits and vegetables. Academic, London.

Egger, E. 1986. I modelli previsionali nella difesa dells vite. Informatore Fitopatologico 9:15-21.

Fisher, R.L. and A.B. Bennett. 1991. Role of cell wall hydrolyses in fruit ripening. Annu. Rev, Plant Physiol. Mol. Biol. 42:675-708.

Fokkema, N.J. and M.P. de Nooij. 1981. The effect of fungicides on the microbial balance in the phyllosphere. European Plant Protection Organization Bul. 11:203-310.

Grainger, J. 1956. The economic effects of crop disease: A preliminary investigation. Bul. West Scotland Agr. College 16: 1-80.

Harrow, K.M. and S. Harris. 1969. Artificial curing of onions for control of neck rot (Botrytis allii Munn.). New Zealand J. Agr. Res. 12:592-604.

Hayward, A.C. 1974. Latent infections by bacteria. Annu. Rev. Phytopathol. 12:87-97.

Hondelmann, W. and E. Richter. 1973. Über die Anfalligkeit von Erdbeerklonen gegen Botrytis cinerea Pers. in Abhangigkeit von Pektinquantität und qualität der Früchte. Gartenbauwissenschaft 38:311-314.

Jarvis, W.R. 1962. The infection of strawberry and raspberry fruits by Botrytis cinerea Pers. Ann. Appl. Biol. 50:569-575.

Jarvis, W.R. 1963. Grey mould of soft fruit. Autecology of Botrytis cinerea. Rpt. Scottish Hort. Res, Inst. 10:77-78.

Jarvis, W.R. 1964. The effect of some climatic factors on the incidence of grey mould in strawberry and raspberry fruit. Hort. Res. $3: 65-71$.

Jarvis, W.R. 1969. The phenology of flowering in strawberry and raspberry in relation to grey mould control. Hort. Res. 9: 8-17.

Jarvis, W.R. 1977. Botryotinia and Botrytis species: Taxonomy, physiology, and pathogenicity. Can. Dept. Agr. Monogr. 15.

Jarvis, W.R. 1980. Epidemiology, p. 219-250. In: J.R. Coley-Smith, K. Verhoeff, and W.R. Jarvis (eds.). The biology of Botrytis. Academic, London.

Jarvis, W.R. 1992. Managing diseases in greenhouse crops. APS Press, St. Paul, Minn.

Jarvis, W.R. and H. Borecka. 1968. The susceptibility of strawberry flowers to infection by Botrytis cinerea. Hort. Res. 8:147-1 54 .

Jenkins, P.T. and C. Reinganum. 1965, The occurrence of a quiescent infection of stone fruits caused by Sclerotinia fructicola (Wint.) Rehm. Austral. J. Agr. Res. 16:131-140.

Johnson, K.V. and M.L. Powelson. 1983. Influence of prebloom disease establishment by Botrytis cinerea and environmental and host factors on gray mold pod rot of snap bean. Plant Dis. 67: 1198-1202.

Kable, P.F. 1971, Significance of short-term latent infections in the control of brown rot in peach fruits. Phytopathol. Z. 70:173-176.

Lakshiminarayana, S., N.F. Sommer, V. Polito, and R.J. Fortlage. 1987. Development of resistance to infection by Botrytis cinerea and Penicillium expansum in wounds of mature apple fruits. Phytopathology 77:1674 1678.

Leben, C. 1981. How plant-pathogenic bacteria survive. Plant Dis. 65:633-637.

Marois, J. J., J.C. Redmond, and J.D. MacDonald. 1988. Quantification of the impact of environment on the susceptibility of Rosa hybrids flowers to Botrytis cinerea. J. Amer. Soc. Hort. Sci. 113:842-845. 
Mason, D.T. and C. Dennis. 1978. Post-harvest spoilage of Scottish raspberries in relation to pre-harvest fungicide sprays. Hort. Res. 18:4 1-53.

McClellan, W.D. and W.B. Hewitt. 1973. Early botrytis rot of grapes: Time of infection and latency of Botrytis cinerea Pers. in Vitis vinifera L. Phytopathology 63: 1151-1 156

McClellan, W.D., W.B. Hewitt, P. La Vine, and J. Kissler. 1973. Early botrytis rot of grapes and its control. Amer. J. Enol., Viticult. 24:27-30.

McNicol, R. J., B. Williamson, and A. Dolan. 1990. Effects of inoculation, wounding, and temperature on post-harvest grey mould (Botrytis cinerea) on red raspberry. J. Host. Sci. 65: 157-165.

Menelly, J.C. and M.E. Stanghellini. 1975. Establishment of an inactive population of Erwinia carotovora in healthy cucumber fruit. Phytopathology 65:670-673.

Perombelon, M.C.M. and A. Kelman. 1988. Ecology of the soft rot Erwinias. Annu. Rev. Phytopathol. 18:361-387.

Pezet, R. and V. Pent. 1986. Infection florale et latence de Botrytis cinerea clans les grappes de Vitis vinifera (var. Gamay). Rev. Suisse Viticult. 18:317322.

Powelson, R.L. 1960. Initiation of strawberry fruit rot caused by Botrytis cinerea. Phytopathology 50:491-494.

Roberts, R.G. 1994. Integrating biological control into postharvest disease management strategies. HostScience 29:758-762,

Rosenberger, D.A. 1983. Observations on quiescent brown rot in infections in Grand Prize plums. Proc. Brown Rot Stone Fruit Wkshp. Deciduous Tree Fruit Diseases Workers, Amer. Phytopathol. Soc. p. 19-22.

Samish, Z. and D. Dimant. 1959. Bacterial population in fresh, healthy cucumbers. Food Manufacture p. 17-20.

Samish, Z. and R. Etinger-Tulczynska. 1963. Distribution of bacteria within the tissue of healthy tomatoes. Appl. Microbiol. 11:8-10.

Schroeder, C.A. 1965. Temperature relationships of fruits under extreme conditions. Proc. Amer. Soc. Hort. Sci. 87: 199-203.

Simmonds, J.H. 1941. Latent infection in tropical fruits discussed in relation to the part played by species of Gloeosporium and
Colletotrichum. Proc. Royal Sot. Queensland 52:92-120.

Smith, M. A., L.P. McColloch, and B.A. Friedman. 1966. Market diseases of asparagus, onions, beans, peas, carrots, celery and related vegetables. U.S. Dept. Agr. Agr. Hdbk. 303,

Stall, R. E., C.C. Hortenstine, and J.R. Iley. 1965. Incidence of botrytis gray mold of tomato in relation to a calcium-phosphorus balance. PhytopatholOgy 55:447-449.

Swinburne, T.R. 1983. Quiescent infections in post-harvest diseases, p. 1-21. In: C. Dennis (ed.), Post-harvest pathology of fruits and vegetables, Academic, London.

Tahvonen, R. 1985. The prevention of Botrytis cinerea and Sclerofinia sclerotiorum on carrots during storage by spraying the tops with fungicide before harvesting. Ann. Agr. Fenniae 24:89-95.

Takeda, Y. and E.R. Nakamura. 1990. Physiological responses of stored fruit in infection stress caused by grey mould (Botrytis cinerea). J. Jpn. Soc, Hort. Sci. 59:657-663.

Tichelaar, G.M. 1967. Studies on the biology of Botrytis allii on Allium cepa Neth. J. Plant Pathol. 73:157-160.

Tronsmo, A. and J. Raa. 1977. Life cycle of the dry eye rot pathogen Botrytis cinerea on apple. Phytopathol. Z. 89:203-207.

Vanderplank, J.E. 1963. Plant diseases: Epidemics and control. Academic, London.

Verhoeff, K. 1968. Studies on Botrytis cinerea in tomatoes. Effect of soil nitrogen level and of methods of deleafing upon the occurrence of Botrytis cinerea under commercial conditions. Neth, J. Plant Pathol. 74: 184- 192,

Verhoeff, K. 1970. Spotting of tomato fruits caused by Botrytis cinerea. Neth. J. Plant Pathol. 76:219-226.

Verhoeff, K. 1974. Latent infections by fungi. Annu. Rev. Phytopathol. 12:99-110. Williamson, B., R.J. McNicol, and A. Dolan. 1987. The effect of inoculating flowers and developing fruits with Botrytis cinerea on post-harvest grey mould of red raspberry. Ann. Appl. Biol. 111:285-295.

Wilson, C.L. 1989. Managing the microflora of harvested fruits and vegetables to enhance resistance. Phytopathology 79:1387-1389.

\title{
Enhancing the Natural Resistance of Plant Tissues to Postharvest Diseases through Calcium Applications
}

\author{
William S. Conway \\ Horticultural Crops Quality Laboratory, Beltsville Agricultural Research Center-West, Beltsville, MD 20705 \\ Carl E. Sams \\ Department of Plant and Soil Science, The University of Tennessee, Knoxville, TN 37901 \\ Arthur Kelman \\ Department of Plant Pathology, North Carolina State University, Raleigh, NC 27695
}

Elucidating and enhancing natural mechanisms of resistance to postharvest diseases currently is of paramount importance, especially concerning storage organs. Consumers are concerned about residues left on produce by postharvest fungicide treatments, and the use of such chemicals is becoming more restricted because of their increasing association, either real or imagined, with human maladies. Since $\mathrm{Ca}$ has often been associated with disease resistance, increasing the amount of $\mathrm{Ca}$ in plant storage organs by various methods is a means of enhancing natural resistance.

Early research into the effects of $\mathrm{Ca}$ on fruit and vegetable quality was concerned mainly with Ca's association with physiological disorders (DeLong, 1936). Subsequently, more than 30 Ca-related disorders in various crops have been identified (Shear, 1975). Disorders of storage organs of fruits and vegetables appear closely related to low $\mathrm{Ca}$ content in tissues. Storage disorders of apples (Malus domestics Borkh.), such as water core, bitter pit, internal breakdown, and softening, have been reduced by postharvest Ca treatment (Bangerth et al., 1972; Mason et al., 1975; Reid and Padfield, 1975). Similarly, with certain potato (Solarium tuberosum L.) cultivars, disorders such as internal brown spot in tubers (Tzeng et al., 1986) and subapical necrosis in sprouts (Dyson and Digby, 1975; Tzeng et al., 1986) were reduced by treatments that increased tissue Ca content.

With certain storage organs, increases in tissue $\mathrm{Ca}$ content led to reductions in decay caused by fungi and bacteria (Huber, 1981). In England, preharvest $\mathrm{Ca}$ sprays reduced storage losses caused by Gloeosporium spp. in apple (Sharples and Johnson, 1977). In the United States, postharvest treatments that increased tissue Cain apples reduced postharvest decay caused by Penicillium expansum Link ex. Thorn (Conway, 1982; Conway and Sams, 1983). Likewise, with potatoes, bacterial soft rot caused byErwinia carotovora pv. atroseptica (van Hall) Dye decreased as tissue Ca increased (McGuire and Kelman, 1984, 1986).

Research concerning the effects of $\mathrm{Ca}$ on apple tissue resistance to postharvest decay has progressed similarly, but independently, of that with potato. The results and conclusions have been similar, and each supported and strengthened the other. Below, we discuss factors and mechanisms in treating apples and potatoes with $\mathrm{Ca}$ to reduce the potential for postharvest decay.

\section{CALCIUM TREATMENT METHODS}

Many disorders that result from inadequate $\mathrm{Ca}$ in storage organs may arise from poor $\mathrm{Ca}$ distribution rather than low $\mathrm{Ca}$ uptake, because, in the same plant, leaves are often higher in Ca concentration than storage organs and concentrations vary widely in specific tissues for a given organ (Bangerth, 1979). Various methods of increasing the 